ఠ

CORRIGENDUM

\title{
Itolizumab - a humanized anti-CD6 monoclonal antibody with better side effects profile for the treatment of psoriasis [Corrigendum]
}

Menon R, David BG. Clinical, Cosmetic and Investigational Dermatology. 2015;8:215-222.

On page 215, please note correspondence should have been listed as:

Roshni Menon,

D II/17, JIPMER Campus, Dhanvanthri Nagar,

Pondicherry, India 605006

Tel +919443208140

Email roshnijagdish@gmail.com

On page 215, the first sentence of the Introduction was "Psoriasis is a chronic inflammatory disease of the skin characterized by exacerbations and remissions affecting $1 \%-3 \%$ of the world's population, and approximately $20 \%$ of patients have moderate to severe disease., ${ }^{1,2}$ " however should have been "Psoriasis is a chronic inflammatory disease of the skin characterized by exacerbations and remissions affecting $1 \%-3 \%$ of the world's population. Approximately $20 \%$ of patients have moderate to severe disease. ${ }^{1,2}$ "

On page 217,219 , and 221 the running header was "Itolizumab - aCD6 monoclonal antibody for the treatment of psoriasis" however should have been "Itolizumab - a humanized anti CD6 monoclonal antibody for the treatment of psoriasis".

On page 218, Table 1, the second column heading was listed as "Anand et $\mathrm{al}^{25} \mathrm{n}=40$ (moderate-severe psoriasis)" however should have been "Anand et $\mathrm{al}^{25} \mathrm{n}=40 / 32$ weeks (moderatesevere psoriasis)".
Clinical, Cosmetic and Investigational Dermatology

\section{Publish your work in this journal}

Clinical, Cosmetic and Investigational Dermatology is an international, peer-reviewed, open access, online journal that focuses on the latest clinical and experimental research in all aspects of skin disease and cosmetic interventions. All areas of dermatology will be covered; contributions will be welcomed from all clinicians and

\section{Dovepress}

basic science researchers globally. This journal is indexed on CAS The manuscript management system is completely online and includes a very quick and fair peer-review system, which is all easy to use. Visit http://www.dovepress.com/testimonials.php to read real quotes from published authors. 